
\section{Restrictions on} \section{foreign students}

\section{cause alarm}

\section{Washington}

Government interference in academic research, ostensibly to control the export of technical data, has stung the presidents of five top universities to protest. The Pentagon is seeking to limit the involvement of foreign research students on certain projects. The universities have also protested, in a letter to Defense Secretary Casper Weinberger and Secretary of State Alexander Haig at attempts to restrict the publication of unclassified research sponsored by the Pentagon.

The university presidents express concern about guidelines issued recently by the department in which defence officials suggest that universities should limit the involvement of foreign students in research related to the development of very high speed integrated circuits (Nature 289, $736 ; 1981)$. They complain that at least one university has been told by the Department of Commerce not to allow certain foreign scholars to participate in its sponsored research activities - a reference to the Export Administration Regulations restricting the transfer of technical data and equipment to communist nations. More action along these lines is expected.

The signatories to the letter are Donald Kennedy, president of Stanford University; Marvin L. Goldberger, president of the California Institute of Technology; Paul E. Gray, president of the Massachusetts Institute of Technology; Frank H. T. Rhodes, president of Cornell University; and David S. Saxon, president of the University of California. According to the text of the letter, not yet officially released by the universities, the full-scale classification of research, where appropriate, is "far preferable" to the application of "restrictive and virtually unenforceable regulations" to universities. For those university activities which remain unclassified, they add, the government should give up all attempts to apply the restrictions until broader issues - which include a possible conflict with the first amendment to the constitution, guaranteeing freedom of speech - have been resolved.

Two sets of export restrictions lie at the heart of the universities' concern. The first is the International Traffic in Arms Regulations, introduced by Congress in the early 1970 s to limit the export to any country of technology (including technical knowhow) of potential military value. The

second is the Export Administration Regulations of the Department of Commerce, aimed at limiting the export of technology of commercial value to certain countries, particularly those in Eastern Europe.

Confusion has arisen in universities and scientific organizations - and in the federal agencies themselves - largely because of the difficulty in drawing a clear line between basic knowledge obtained by scientific research and results which, although still described as "basic", have been developed with a particular long-term military or commercial aplication in mind.

Last year, for example, the regulations were invoked by the Department of Commerce to prevent scientists from Eastern Europe from attending an open meeting on computer bubble memories organized by the American Vacuum Society, one of more than 40 scientific societies which have since applied for exemptions from the export controls for future scientific meetings on the grounds that, since these are open meetings, they should not be considered to involve the transmission of "secret" data.

The concern expressed by the five

\title{
Gowans washes hands of Rothschild
}

\section{New York}

Recent changes in the organization of medical research in the United Kingdom mean that the customer-contractor basis proposed by Lord Rothschild between the Medical Research Council (MRC) and the Department of Health and Social Security (DHSS), "has now been abandoned", Dr James Gowans, director of MRC, told an audience at the Rockefeller University in New York last week.

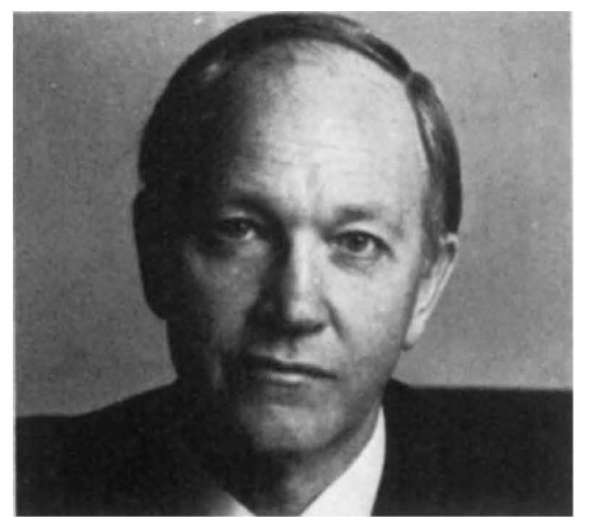

Gowans - Rothschild off his back

Describing the British approach to medical research funding, Dr Gowans said that after the customer--contractor relationship was introduced in 1972, with substantial funds being transferred from MRC to DHSS, only a handful of new contracts had been awarded. "It became apparent that the customer-contractor university presidents, however, applies more specifically to the conditions that must be observed by scientists in US universities and research institutions, and their freedom to publish the results of their research or to communicate it to nonAmerican scientists through seminars or even informal discussions.

Officials at Cornell University, for example, said last week that in one recent instance the Department of Commerce had placed conditions on a foreign scientist's visit, restricting his access to research at the university, which it had not been prepared to accept, and the visit had been cancelled. In another instance, a research contract proposed by the Department of Defense specified that, although the research was to be unclassified, the department's permission was required before any results were published - a condition which many universities, such as Stanford, say they would find unacceptable.

The five university presidents point out that although the regulations have existed for several years, only recently have they begun to be applied to "traditional university activities". The new interpretation could result in restrictions which

principle was not applicable to medical research, certainly not on the scale envisaged by Rothschild.

Following further discussions, the Rothschild arrangement had been abandoned and the money previously transferred to DHSS had been transferred back to MRC. "We are now back in the situation that we were in before 1972', $\mathrm{Dr}$ Gowans said, adding that "to a scientist it is gratifying", since many members of the scientific community had argued strongly against Rothschild's ideas when they first appeared.

MRC and DHSS "both now realize that fundamental solutions to problems such as cancer and coronary heart disease cannot be conjured up by the use of contracts. It is not possible to use bureaucratic devices to accelerate the rate of scientific progress", he added. As part of the new arrangements, MRC had also agreed to undertake more health services research, since the council had been told that much of the work carried out under that heading was very important but not very well done.

Mistakes had arisen in government science policy through a failure to distinguish between areas of research - such as cancer research - where the basic principles were not known and the science could not be substantially accelerated merely by providing additional funding, and areas where the scientific principles were known and additional support would provide more substantial results.

David Dickson 
would conflict with the fundamental precepts that define the role and operation of the American university system, they say. Strict interpretation, coupled with the severe criminal penalties that they contain, would be even more restrictive than direct classification of the research.

In response to the letter, whose addressees also include $\mathrm{Mr}$ Malcolm Baldrige, the Secretary of Commerce, the three federal agencies involved have apparently told the universities that they are looking closely at the problems raised, but it is expected to be several weeks before a formal reply is agreed upon.

The potential impact of the export control regulations on the academic community is already being discussed by an ad hoc committee set up last month by the National Academy of Science's Committee on Science and Public Policy.

The rules are also being closely studied by the National Science Foundation. Dr Donald Langenburg, the Deputy Director, says the foundation is "deeply concerned" about the potential impact of export controls on research, adding that it is "critical" to the freedom of scientific exchange that these are kept to a minimum consistent with foreign policy and national security objectives.

The growing tension between the academic community and the federal agencies over the interpretation of export restrictions is precisely the type of problem for a presidential science adviser, still absent from the White House.

David Dickson

\section{DNA research guidelines}

\section{Dutch get tough}

\section{Brussels}

The publication by an ad hoc committee of revised safety rules for recombinant DNA research has raised some grumbles in Dutch industrial circles. By and large the new guidelines, the conclusions of a year's study of the risks of gene manipulation, follow closely those set by the National Institutes of Health in the United States. But while other European countries are moving towards a relaxation of the rules, the Dutch have tightened up the restrictions on research with pathogenic microorganisms.

Companies such as Unilever and GestBrocades, which are carrying out research into the industrial applications of bioengineering are, however, more frustrated about the administrative checks on research. In the Netherlands, DNA research is first vetted by the ad hoc committee, although there is no legal obligation to register the research. Local authorities then have the last word over individual experiments and any new research laboratories.

It is up to the committee, the local authority and university advisory groups to interpret the guidelines as they see fit. Industry complains that it is unnecessarily restrictive to ask permission to carry out each individual experiment. Unilever has taken some of its projects to Belgium and Gest-Brocades has switched some of its resources to its UK laboratories. In the meantime both expect to wait at least a year for approval on new laboratories. The companies feel that local government authorities are much harder on industry than on universities.

The Netherlands is now thought to have the toughest rules in the world. Public distrust of DNA research caused four members of the ad hoc committee to abstain from the final vote on the new guidelines on the grounds that there should be a study of the impact of genetic engineering on society as a whole.

The European Community's Economic and Social Committee is taking the same option. Last July the European Commission brought out its own recommendation on the registration of DNA research, which stressed that over the past three years it had become clear that DNA research is not as dangerous as was originally thought. However, before agreement is reached between the Economic and Social Committee and the European Parliament, a public workshop is to be held in May that will bring together representatives from a cross-section of society to discuss the economic, social and ethical implications of such research.

The Commission's recommendation, if it is adopted, would do little more than establish common definitions and provide the basis for a consensus on registration procedures. However, many researchers increasingly feel that arguments about risk assessments are academic. The bulk of research is carried out in the lowest risk class and very rarely in PIII containment conditions. Thus, the slightly stricter rules proposed by the Dutch are expected to have little impact.

Jasper Becker

\section{Solar Polar mission}

\section{Joint project saved?}

The European Space Agency (ESA) is "cautiously optimistic" that something will be salvaged from the International Solar Polar Mission, although in a less ambitious form than originally envisaged. The two-spacecraft mission to study the polar regions of the Sun was threatened last month when the US National Aeronautics and Space Administration (NASA) announced that, to meet budget cuts, it would not be building its spacecraft.

Although it is unlikely that NASA will restore the mission to its original status, angry protests and diplomatic pressure by European embassies in Washington seem to have prompted a compromisé. According to ESA, that might involve NASA building a cheaper spacecraft costing $\$ 40$ million rather than the $\$ 100$ million originally planned.

Under such a scheme, NASA's space-
Congress redisposes

\section{Washington}

A congressional subcommittee has now prepared the ground for restoring the United States half of the Solar Polar Mission. Last week, the space science subcommittee of the House of Representatives Science and Technology Committee voted to make cuts elsewhere in the National Aeronautics and Space Administration's (NASA's) budget for the fiscal year 1982; these cuts made it possible for the subcommittee to restore money for projects such as the Solar Polar Mission (which was given an additional $\$ 15$ million) without exceeding the total for the NASA budget of $\$ 6,700$ million proposed by Mr Reagan. Since the rearranged budget package will not incur additional costs, House Democrats are hopeful that the pro-space science subcommittee of the Senate Commerce Committee, which votes later this month on NASA's authorization, can also be persuaded to accept reinstatement of the solar spacecraft, perhaps on a smaller scale.

David Dickson

craft, which would lose a de-spun platform carrying a solar coronograph for direct imaging of the Sun, would be almost identical with ESA's. Two similar spacecraft would allow measurements of spatially and temporally resolved dynamic phenomena, which would not be possible with only one.

ESA's dismay at NASA's decision to abandon its part of the mission was largely due to the fact that it had already spent most of the money for its spacecraft in European industry. NASA, on the other hand, had delayed building its craft after the planned launch date of the mission was put back last year. If NASA is willing to compromise, ESA will agree to a further launch delay to 1986 , even though it would increase the costs. The precise details of the compromise will have to wait until $\mathrm{Dr}$ James Beggs, NASA's new director, is installed.

Judy Redfearn

\section{Biotechnology}

\section{Canada takes stock}

\section{Washington}

After six months of intensive study, a task force set up last summer to look at the development of biotechnology in Canada has recommended that the Canadian government should establish a ten-year National Biotechnology Development Plan, with a budget that would rise to about $\$ 50$ million a year. Most of this money would go on research and training; exploitation would remain for the private sector, which the task force recommends should receive significant tax incentives.

The task force was set up by Canada's Minister of State for Science and Technology, Mr John Roberts, and was 